\title{
Overview of 5-ASA in therapy of inflammatory bowel disease
}

\author{
CN WILLIAMS MD FRCPC
}

CN WILLIAMS. Overview of 5-ASA in therapy of inflammatory bowel disease. Can J Gastroenterol 1994;8(6):379-382. There are two forms of 5-aminosalicylic acid (5-ASA) drug delivery. First, a pro-drug form in which 5-ASA, the active principal, is attached to a Garrier molecule and released in the intestine by bacterial cleavage. An example of this is sulfasalazine, originally developed in the 1940 s and found to be effective, cheap, but limited by side effects due to the sulfapyridine component. The second drug delivery system depends on an enteric coating for delayed $\mathrm{pH}$-dependent release or for a timed-released mechanism. 5-ASA inhibits 5-lipoxygenase, modulates leukocyte function and inhibits soluble mediator release, and is an effective scavenger action of free oxygen radicals, the relative importance of which is unknown. The multiplicity of action is probably its strength because drugs that have only one of these actions are relatively ineffective in inflammatory bowel disease. 5-ASA compounds are effective in treating mild to moderate acute ulcerative colitis and in maintaining remission, and are equivalent to sulfasalazine in this regard. 5-ASA used topically in enema or suppository form is highly efficient in both acute disease and in maintaining remission. 5-ASA is also effective in active Crohn's disease, but not as effective as in maintenance therapy compared with ulcerative colitis. The pro-drugs tend to have more side effects. Slow release compounds are well tolerated with few side effects, allowing increases to effective dosage. In patients intolerant of sulfasalazine, switching to a 5-ASA preparation usually results in tolerance and therapeutic benefit, with an occasional allergic reaction to the 5-ASA molecule limiting its use.

Key Words: 5-Aminosalicylic acid, Crohn's disease, Sulfasalazine, Ulcerative colitis, Ulcerative proctitis

\section{Le 5-AAS dans le traitement de la maladie inflammatoire de l'intestin}

RÉSUMÉ : Il existe deux formes posologiques d'acide 5-aminosalicylique (5AAS). Ce dernier existe en effet sous la forme d'un précurseur de médicament et le principe actif (5-AAS) est alors fixé à une molécule porteuse, puis libéré dans l'intestin lors de sa lyse par les bactéries. La sulfasalazine en est un exemple; elle fut découverte dans les années quarante et jugée efficace et peu coûteuse, quoique

voir page suivante Scotia

Division of Gastroenterology, Department of Medicine, Dalhousie University, Halifax, Nova

Correspondence and reprints: Dr CN Williams, Professor and Head, Division of Gastroenterology, Department of Medicine, Dalhousie University, 5849 University Avenue, Halifax, Nova Scotia B3H 1 W2

This paper was presented at the Trends in Inflammatory Bowel Disease Therapy meeting, April 6 to 9, 1994, held in Victoria, British Columbia. This paper has also been published in Sutherland LR, et al, eds. Inflammatory Bowel Disease: Basic Research, Clinical Implications and Trends in Therapy. Boston, Dordrecht and London: Kluwer Academic Publishers, 1994
S ULFASALAZINE (SAS) WAS DEVEL oped in the early 1940s (1) as an anti-inflammatory, antibiotic for use in rheumatoid arthritis, then thought to have an infectious etiology. 5-aminosalicylic acid (5-ASA) is the active principal of SAS. 5-ASA is available in carrier-mediated form. Here, the prodrug is delivered to the large intestine, where bacterial action breaks an azo bond (2) and releases the active principal. For SAS, the release is of the active principal, 5-ASA, and inactive sulphapyridine $(3,4)$. For olsalazine (Dipentum; Pharmacia), splitting the azo bond releases two molecules of 5 ASA. Other pro-drugs, balsalazide and ipsalazide, are not available in Canada (5). Enteric-coated, slow-release, pHdependent forms of 5-ASA are available in North America: Asacol (Procter and Gamble), Salofalk (Axcan), Rowasa (Solvay Pharmaceuticals; Georgia) (Table 1). These preparations avoid excessive upper intestinal absorption and theoretical renal damage (6). Salofalk and Rowasa are released in the distal ileum, Asacol in the right colon (7). Another preparation, Pentasa (Nordic), is a formulation of 5-ASA granules covered with ethyl cellulose. This allows slow release starting in the proximal small bowel (8).

While SAS inhibits both the lipoxygenase and cyclooxygenase arachidonic acid pathways, 5-ASA inhibits leukotriene production by inhibiting 5-lipoxygenase in the cyclooxygenase pathway (9). 5-ASA acts on soluble mediator production. It modulates leukocyte function. It is an inhibitor of prostaglandins, thromboxanes, platelet-activating factor, tumour necrosis 
limitée par des effets secondaires liés à sa composante sulfapyridine. La libération de la deuxième forme posologique dépend d'un enrobage entérique et est alors liée au $\mathrm{pH}$ ou à un mécanisme à longue action. Le 5-AAS inhibe la 5-lipoxygénase, module la fonction leucocytaire et bloque la libération des médiateurs solubles, et il exerce un effet piégeur efficace des radicaux libres de l'oxygène, dont l'importance est inconnue. Ce rôle multiple est probablement son principal atout parce que les médicaments qui n'exercent que l'une des ces actions sont relativement inefficaces dans la maladie inflammatoire de l'intestin. Les composés à base de 5-AAS sont efficaces dans le traitement de la colite ulcéreuse aiguë, de légère à modérée, et dans le maintien de la rémission et ils équivalent à la sulfasalazine à cet égard. Utilisé par voie topique sous forme de lavement ou en suppositoire, le 5-AAS est très efficace dans la maladie aiguë et pour le maintien de la rémission. Le 5-AAS est aussi efficace dans la maladie de Crohn, mais pas aussi efficace en traitement d'entretien comparativement à la colite ulcéreuse. Les précurseurs de médicaments tendent à produire davantage d'effets secondaires. Les molécules à libération prolongée sont bien tolérées et s'accompagnent de peu d'effets secondaires, ce qui permet d'en augmenter la dose pour obtenir plus d'efficacité. Chez les patients qui ne tolèrent pas la sulfasalazine, le passage à une préparation de 5-AAS est généralement bien toléré et bénéfique, une réaction allergique à la molécule de 5-AAS pouvant occasionnellement en restreindre l'usage.

factor, interleukin-1, intestinal mast cell and basophil-stimulated histamine release. It is an effective scavenger of free oxygen radicals (10). The relative importance of these actions is not known.

5-ASA is metabolized to one end product only in humans, $\mathrm{N}$-acetyl-5. ASA (11), and is independent of acetylation phenotype (12). This probably occurs by bacterial action in the colonic lumen as well as in the mucosal cell (13) and the hepatocyte (14). N-acetyl5-ASA is believed to have no biological action (15) and is excreted by the kidneys. Factors affecting oral 5-ASA disposition include food intake, omeprazole, luminal $\mathrm{pH}$, intestinal transit time, $\mathrm{co}-$ lon flora and antibiotics. Crohn's disease alters 5-ASA absorption and is reversed towards normal after effective treatment (16). There are few available studies of intestinal $\mathrm{pH}$ in patients with inflammatory bowel disease (IBD). However, using serum, urine and stool measurements, increasing proportions of nonmetabolized 5-ASA reach the colon from the slow release (Pentasa) through the enteric-coated (Salofalk, Asacol) to the pro-drugs (olsalazine, SAS). Topical formulations of 5-ASA are available as enemas, suppositories and foams.

The pro-drug SAS is associated with an approximate $30 \%$ incidence of side effects, predominantly related to the sulphapyridine component (17). Desensitization is helpful for some, but not for hypersensitivity reactions such as agranulocytosis, hemolysis or aplastic anemia. Other rare side effects include male infertility and folate deficiency. Side effects associated with 5-ASA tend to be dose-related and infrequent in number; headache, nausea, epigastric distress and diarrhea are common (18). Rare complications of 5-ASA include acute pancreatitis (19), pericarditis (20), myocarditis (21), thrombocytopenia (22) and renal tubular damage (23). Rarely, both drugs may exacerbate the IBD $(24,25)$.

5-ASA is recommended for the treatment of patients with mild to moderate IBD. The type of 5-ASA used depends on the type of disease (Crohn's disease or ulcerative colitis), and the site and extent of disease. Oral 5-ASA drugs, including the pro-drugs, are probably equally effective when universal ulcerative colitis is present. Suppositories are the treatment of choice for distal disease of $20 \mathrm{~cm}$ or less; enemas are used when there is 20 to $40 \mathrm{~cm}$ of disease. Enemas are particularly effective in universal colitis, together with an oral 5-ASA, when rectal symptoms predominate. 5-ASA is particularly useful in Crohn's disease with colonic involvement with or without limited ileal disease. Pentasa is probably the theoretical drug of choice in more proximal small bowel disease because of its mechanism, but this remains to be shown by clinical trial. 5-ASA appears to induce remission more slowly than corticosteroids and is more expensive. However, patient tolerability, especially for the topical formulations, is high and there is less toxicity.

5-ASA is effective in treating IBD (26). Its exact efficacy is difficult to ascertain from careful literature review due to: lack of accurate definitions of remission versus improvement; failure to define the exact type or extent of IBD; whether placebo or active drugs are used for controls; different end-points -

\section{TABLE 1}

\section{5-aminosalicylic (5-ASA) drugs available in North America}

\begin{tabular}{|c|c|c|c|}
\hline Drug & Company & Coating & Delivery mechanisms \\
\hline Salofalk $250,500,750 \mathrm{mg}$ & Axcan & Eudragit L & $\mathrm{pH}>6.0$ \\
\hline Mesasal 250, $500 \mathrm{mg}$ & SmithKline Beecham & Eudragit L & $\mathrm{pH}>6.0$ \\
\hline Rowasa* $250,500 \mathrm{mg}$ & Solvay Pharmaceuticals & Eudragit LH & $\mathrm{pH}>6.0$ \\
\hline Pentasa $250 \mathrm{mg}$ & Nordic & Ethyl cellulose & Slow release \\
\hline $\begin{array}{l}\text { Dipentum (olsalazine) } 250 \text { mg capsule, } \\
500 \text { mg tablet }\end{array}$ & Pharmacia & Gelatin capsule, Ec tablet & Bacterial cleavage \\
\hline
\end{tabular}

"Not available in Canada 
clinical, endoscopic or histological; use of different scoring systems; varying doses; different treatment periods; and the absence of power calculations for accurate estimates of number of patients required. Placebo responses in acute ulcerative colitis range from 5 to $38 \%$, and active drug dose responses from 24 to $63 \%$, using doses up to $4.8 \mathrm{~g}$ over three to eight weeks $(27-30)$. Us ing the same dose for different time periods shows a tendency for increased efficacy in clinical response, but not to endoscopic response (31). In maintenance therapy for ulcerative colitis, comparisons of SAS versus placebo over a six - to 12 -month period reveals a therapeutic gain of 43 to $50 \%(32,33)$, with a therapeutic gain of $24 \%$ using increasing doses of SAS (34). There are many studies showing equal efficacy in maintaining remission between SAS and another pro-drug, Dipentum (35), as well as between SAS and entericcoated 5-ASA (36). Meta-analyses have shown that 5-ASA is equivalent to SAS in mild to moderate acute ulcerative colitis and in maintenance therapy $(37,38)$. Similarly, the use of topical 5-ASA in ulcerative colitis is very effective for enemas: 85 to $90 \%$ using $4 \mathrm{~g}$ at nighttime for four to 12 weeks $(39,40)$; for suppositories, similar efficacy was

\section{REFERENCES}

1. Svartz N. Salazopyrin, a new sulphanilamide preparation:

A. Therapeutic results in rheumatic polyarthritis. B. Therapeutic results in ulcerative colitis. C. Toxic manifestations in treatment with sulphanilamide preparations. Acta Med Scand 1942;110:577-98.

2. Peppercorn MA, Goldman P. Distribution studies of salicylazosulfapyridine and its metabolites. Gastroenterology 1973;64:240-5.

3. Azad Khan AK, Piris J, Truelove SC. An experiment to determine the active therapeutic moiety of sulphasalazine. Lancet

1977;ii:891-5.

4. van Hees PAM, Bakker JH, van Tongeren JHM. Effect of sulphapyridine, 5 -aminosalicylic acid and placebo in patients with idiopathic proctitis: a study to determine the active therapeutic moiety of sulphasalazine. Gut 1980;21:632-5.

5. Chan RP, Pope DJ, Gilbert AP, et al. Studies of two novel sulfasalazine noted using either $500 \mathrm{mg}$ twice or three times a day for six weeks $(41,42)$. For maintenance therapy, $1 \mathrm{~g}$ at nighttime for enemas, and $0.5 \mathrm{~g}$ every second night for suppositories are effective treatments. Recent meta-analysis of topical 5-ASA in ulcerative colitis confirms significant benefits over placebo for both active disease and maintenance therapy (43).

5-ASA is effective in active Crohn's disease. There is a $32 \%$ therapeutic gain when SAS, $3 \mathrm{~g} /$ day, is compared with placebo over a four-month period (44). This was later confirmed in the National Cooperative Crohn's Disease Study where a subgroup with colitis responded better (45). In a recent study, a $25 \%$ therapeutic gain with Pentasa versus placebo was seen in 310 patients randomized to various doses over a 16 . week period (46). There was no difference between placebo, $1 \mathrm{~g}$ or $2 \mathrm{~g}$ recipients in this study. In maintenance therapy, Pentasa is beneficial, compared with placebo in a subgroup of patients who had relapsed within three months prior to enrolment (47). Other studies have shown no effect when either Pentasa (48) or SAS (49) was compared with placebo. However, in a large group of patients treated with SAS followed for up to two years, there was

analogs, ipsalazide and balsalazide. Dig Dis Sci 1983;28:609-15.

6. Lauritzen K, Laursen LS, Rask-Madsen J. Review of oral salicylates in the treatment of inflammatory bowel disease. In: Shaffer EA, ed.

Proceedings, Medical Management of IBD. Montreal: Medicopea International Inc, 1992.

7. Dew MJ, Hughes PJ, Lee MG, Evans BK, Rhodes J. An oral preparation to release drugs in the human colon. $\mathrm{Br}$ J Clin Pharmacol 1982;14:405-8.

8. Keller J, Layer P, Klotz U, Goebell H. Small intestinal transit of oral mesalazine (5-ASA) from a microsphere preparation in humans. Proceedings of a Falk Symposium (67). In: Scholmerich J, Goebell H, Kruis W, Hohenberger W, eds. Inflammatory Bowel Diseases. Dordrecht: Kluwer Academic Publishers, 1992.

9. Lauritsen K, Staerk Laursen L, Buhave K, Rask-Madsen J. Longterm olsalazine treatment: pharmacokinetics, tolerance and effects on local eicosanoid formation in ulcerative a therapeutic gain of 25\% (50), and in another study of 12 months' duration, patients randomized to Claversal (SmithKline Beecham) experienced a $24 \%$ therapeutic gain over those randomized to placebo (51). Patients with Crohn's disease had remission rates on placebo varying from 35 to $54 \%$, compared with $60 \%$ on SAS and $78 \%$ on Claversal over 12 months. These findings were confirmed in a recent metaanalysis which found that maintenance therapy with 5-ASA or SAS reduces the likelihood of clinical relapse at one year (52).

5-ASA is a well tolerated medication with few side effects, allowing increase in effective dosage. It is recommended that $4 \mathrm{~g}$ 5-ASA be given orally for active IBD, with increases as necessary. It is uncertain whether continuous active treatment should be advised for maintenance therapy, ie, $4 \mathrm{~g} /$ day or the standard $2 \mathrm{~g} /$ day. Different preparations can be used to target the site of disease, and when given orally, appear to be equally as effective in maintaining remission as SAS. However SAS is much cheaper, and when tolerated, is effective therapy. 5-ASA given to SAS-intolerant patients is of therapeutic benefit in most with the caveat of occasional allergic reaction to 5-ASA.

colitis and Crohn's disease. Gut 1988;29:974-82.

10. Ahnfelt-Ronnel, Hielsen $\mathrm{OH}$, Christensen A, Langholz E, Binder V, Ris P. Clinical evidence supporting the radical scavenger mechanism of 5-ASA. Gastroenterology 1990;98:1162-9.

11. Nielsen OH, Bondesen S. Kinetics of 5-aminosalicylic acid after jejunal installation in man. Br J Clin Pharmacol 1983;16:738-40.

12. Allgayer $\mathrm{H}$, Ahnfeldt NO, Frank K, Soderberg HNA, Kruis W, Paumgartner G. Acetylation phenotype independent colonic $\mathrm{N}$-acetylation of 5-aminosalicylic acid: an example for intestinal drug metabolism. Gastroenterology 1985;88:133. (Abst)

13. Ireland A, Priddle JD, Jewell DP. Acetylation of 5-aminosalicylic acid by human colonic epithelial cells. Gastroenterology 1986;90:1471. (Abst)

14. Myers B, Evans DNW, Rhodes J, et al. Metabolism and urinary excretion of 5 -aminosalicylic acid in healthy 
volunteers when given intravenously or released for absorption at different sites in the gastrointestinal tract. Gut 1987;28:196-200.

15. van Hogezand RA, van Hees PAM, Van Gorp JPWM, et al. Double-blind comparison of 5-aminosalicylic acid and acetyl-5-aminosalicylic acid suppositories in patients with idiopathic proctitis. Aliment Pharmacol Ther 1988;2:33-40.

16. Williams CN. Pharmacokinetics of 5-aminosalicylic acid enteral suspension in Crohn's disease and in healthy volunteers. Can ] Gastroenterol 1990;4:458-62.

17. Watkinson G. Sulphasalazine: a review of 40 years experience. Drugs 1986;32:1-11.

18. Allgayer H. Sulphasalazine and 5-ASA compounds. Gastroenterol Clin North Am 1993;21:643-58.

19. Deprez P, Descamps C, Fiasse R. Pancreatitis induced by 5 -aminosalicylic acid. Lancet 1989;ii:445-6.

20. Agnholt J, Sorensen HT, Rasmussen SN, Gotzsche CO, Halkier P. Cardiac hypersensitivity to 5 -aminosalicylic acid. Lancet 1989;i:1135.

21. Kristensen KS, Hoegholm A, Bohr L, Fries S. Fatal myocarditis associated with mesalazine. Lancet 1991;335:605.

22. Daneshmend TK. Mesalazineassociated thrombocytopenia. Lancet 1991;337:1297-8.

23. Zehnter E, Dorhofer H, Ziegenhagen DJ, Scheurlen C, Baldamus CA, Kruis W. Renal damage in patients with IBD treated with 5-aminosalicylic acid and sulphasalazine. Gastroenterology 1991;100:A264. (Abst)

24. Schwartz AG, Targan SR, Saxon A, Weinstein WM. Sulfasalazine-induced exacerbation of ulcerative colitis. N Engl J Med 1982;306:409-12.

25. Austin CA, Cann PA, Jones TH, Holdsworth CD. Exacerbation of diarrhea and pain in patients treated with 5-aminosalicylic acid for ulcerative colitis. Lancet 1984;i:917-8. (Lett)

26. Williams CN. Efficacy of corticosteroid and mesalazine (5-aminosalicylate) in inflammatory bowel disease. In: Hadziselimovic F, Herzog B, eds. Pediatric Gastroenterology; Inflammatory Bowel Diseases and Morbus Hirschsprung. Dordrecht: Kluwer Academic Publishers, 1992:137-46.

27. Schroeder KW, Tremaine WJ, Istrup DM. Coated oral 5-aminosalicylic acid therapy for mildly to moderately active ulcerative colitis; randomized study. N Engl J Med 1987;317:1625-9.

28. Sutherland LR, Martin F, Greer S, et al. 5-aminosalicylic acid enema in the treatment of distal ulcerative colitis, proctosigmoiditis and proctitis. Gastroenterology 1987;92:1894-8.
29. Meyers S, Lever PK, Feuer EJ, Johnson JW, Janowitz HD. Predicting the outcome of corticosteroid therapy for acute ulcerative colitis; results of a prospective, randomized, double-blind trial. J Clin Gastroenterol 1987;9:50-4

30. Hanauer S, Beshears L, Wilkinson C, et al. Induction of remission in a dose-ranking study of oral mesalamine capsules (Pentasa). Gastroenterology 1990;98:A174. (Abst)

31. Rachmilewicz D on behalf of an international study group. Coated mesalazine 5-aminosalicylic acid versus sulphasalazine in the treatment of active ulcerative colitis; a randomized trial. Br Med J 1989;298:82-6.

32. Misiewicz JJ, Lennard-Jones JE, Connell AM, Baron GH, Avery-Jones F. Controlled trial of sulphasalazine in maintenance therapy of ulcerative colitis. Lancet 1965;i:185-8.

33. Dissanayake AS, Truelove SC. A controlled, therapeutic trial of long-term maintenance treatment of ulcerative colitis with sulphasalazine (Salazopyrine). Gut 1973;14:923-6.

34. Azad-Khan AK, Hows DT, Piris J, Truelove SC. Optimal dose of sulphasalazine for maintenance treatment in ulcerative colitis. Gut 1980;21:232-40.

35. Ireland A, Mason CH, Jewell DP. Controlled trial comparing olsalazine and sulphasalazine for the maintenance treatment of ulcerative colitis. Gut 1988;29:835-7.

36. Rutgeerts P. Comparative efficacy of coated oral 5-aminosalicylic acid (Claversal) and sulphasalazine for maintaining remission of ulcerative colitis. Alim Pharmacol Ther 1989;3:183-92.

37. Rosellini SR, Valipani D, Spada M, Miglio F, Tragnone A, Lanfranchi GA. 5-aminosalicylic acid and sulphasalazine in acute and maintenance treatment of ulcerative colitis; a meta analysis of comparative, randomized trials. Gastroenterology 1991;100:A243. (Abst)

38. Sutherland LR, May GR, Shaffer EA. Sulphasalazine revisited: a metaanalysis of 5-aminosalicylic acid in the treatment of ulcerative colitis. Ann Intern Med 1993;118:540-9.

39. Robinson SG, Decktor DL. Efficacy of 5-aminosalicylic acid enemas in the treatment of distal ulcerative colitis. Can J Gastroenterol 1990;4:468-71.

40. Biddle WL, Miner PB. Long-term use of mesalamine enemas to induce remission in ulcerative colitis. Gastroenterology 1990;99:113-8.

41. Williams CN, Haber G, Aquino J. Double-blind, placebo-controlled evaluation of 5-ASA suppositories in active distal proctitis and measurement of extent of spread using ${ }^{99} \mathrm{~m} \mathrm{~T}$ labelled 5-ASA suppositories. Dig Dis Sci 1987;32:31-5S.

42. Williams CN. Efficacy and tolerance of 5-aminosalicylic acid suppositories in the treatment of ulcerative proctitis; two double-blind, placebo-controlled trials. Can J Gastroenterol 1990;4:472-5.

43. Irvine EJ, Marshall JK. A meta-analysis of topical 5-ASA's for distal ulcerative colitis. In: Sutherland LR, et al, eds. Inflammatory Bowel Disease: Basic Research, Clinical Implications and Trends in Therapy. Boston, Dordrecht and London: Kluwer Academic Publishers, 1994.

44. Anthonisen T, Barany F, Folkenborg $\mathrm{O}$, et al. The clinical effect of salazosulphapyridine (Salazopyrine) in Crohn's disease; a controlled, double-blind study. Scand J Gastroenterol 1974;9:549-54.

45. Summers RW, Switz DM, Sessions JR Jr, et al. National Cooperative Crohn's Disease Study; results of treatment. Gastroenterology 1979;77:847-69.

46. Singleton JW, Hanauer SB, Gitnick GL, et al. Mesalamine capsules for the treatment of active Crohn's disease: results of a 16 week trial. Gastroenterology 1993;104:1293-301.

47. Gendre JP, Marrie JY, Florent C, et al. Does Pentasa prevent relapses in quiescent Crohn's disease? A multicentre, placebo-controlled trial (161 patients). Gastroenterology 1990;98:A171. (Abst)

48. Bondesen S and the Danish 5-ASA group. Mesalazine (Pentasa) as prophylaxis in Crohn's disease; a multicentre, controlled trial. Scand J Gastroenterol 1991;26(Suppl):68. (Abst)

49. Lennard-Jones JE. Sulphasalazine in asymptomatic Crohn's disease; a multicentre trial. Gut 1977;18:69-72

50. Malchow H, Hewe K, Brandes JW, et al. European Cooperative Crohn's Disease Study (E.C.c.D.S.); results of drug treatment. Gastroenterology 1984;86:249-66.

51. Thomson ABR, with international study group. Coated oral 5-aminosalicylic acid versus placebo in maintaining remission in inactive Crohn's disease. Alim Pharmacol Ther 1990;4:55-64.

52. Steinhart AH, Hemphill DJ, Greenberg GR. Sulphasalazine and mesalamine for the maintenance therapy of Crohn's disease: a meta-analysis. In: Sutherland LR, et al, eds. Inflammatory Bowel Disease: Basic Research, Clinical Implications and Trends in Therapy. Boston, Dordrecht and London: Kluwer Academic Publishers, 1994. 


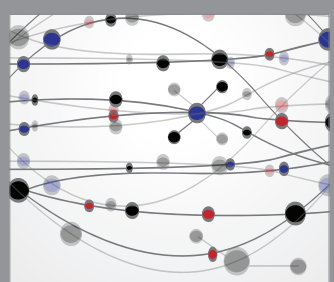

The Scientific World Journal
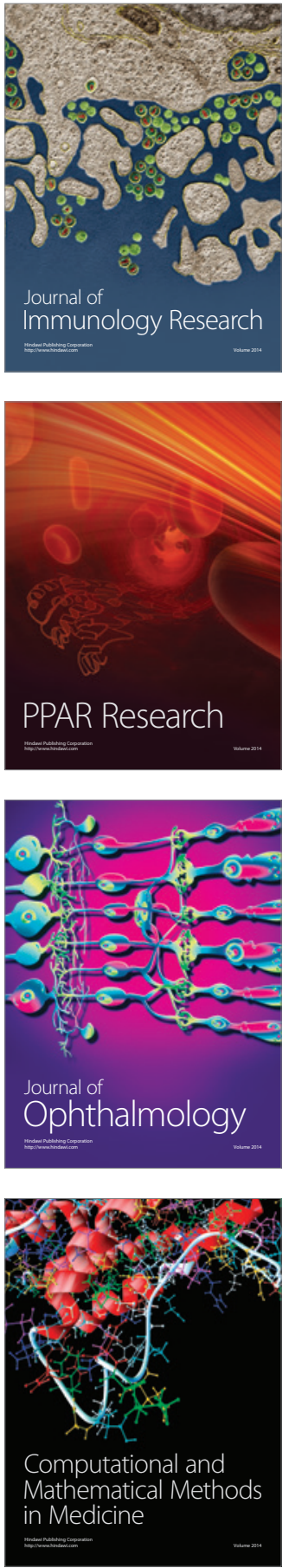

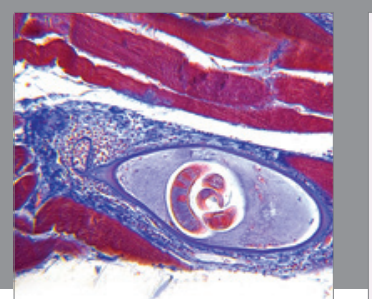

Gastroenterology Research and Practice

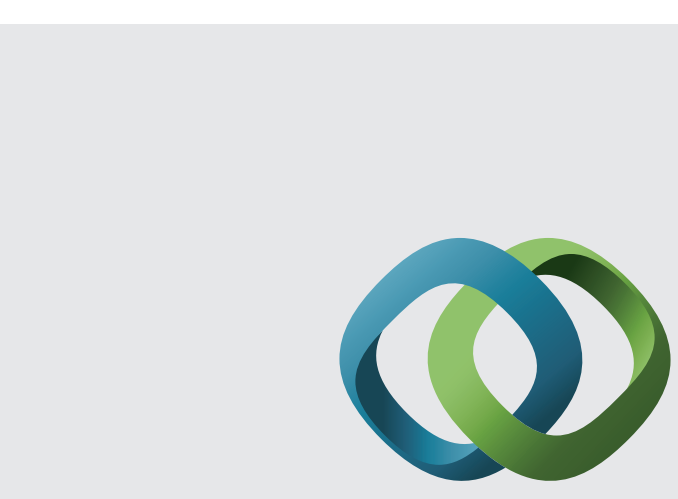

\section{Hindawi}

Submit your manuscripts at

http://www.hindawi.com
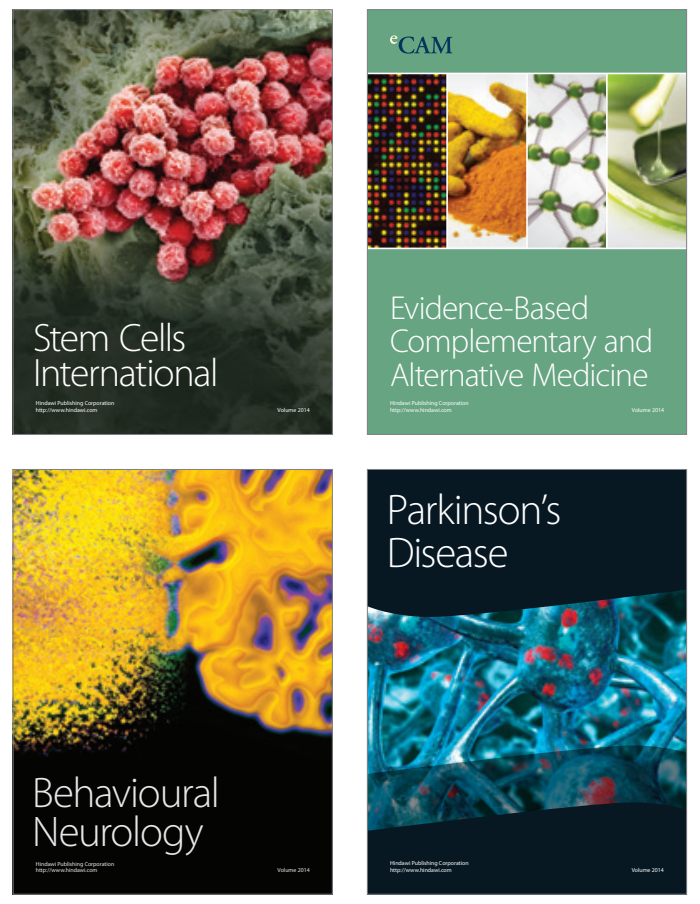
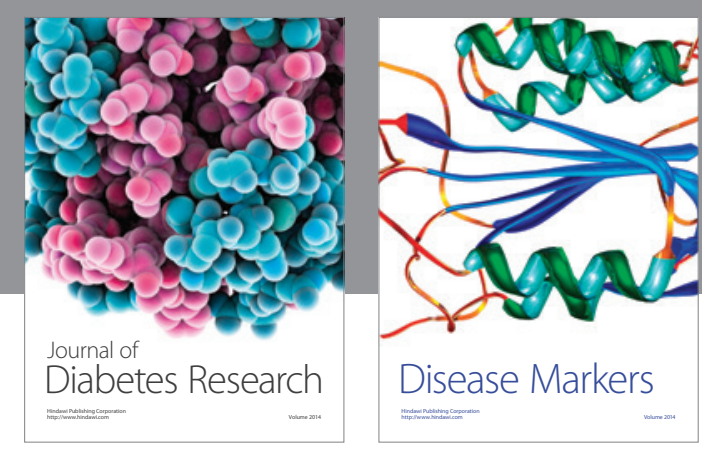

Disease Markers
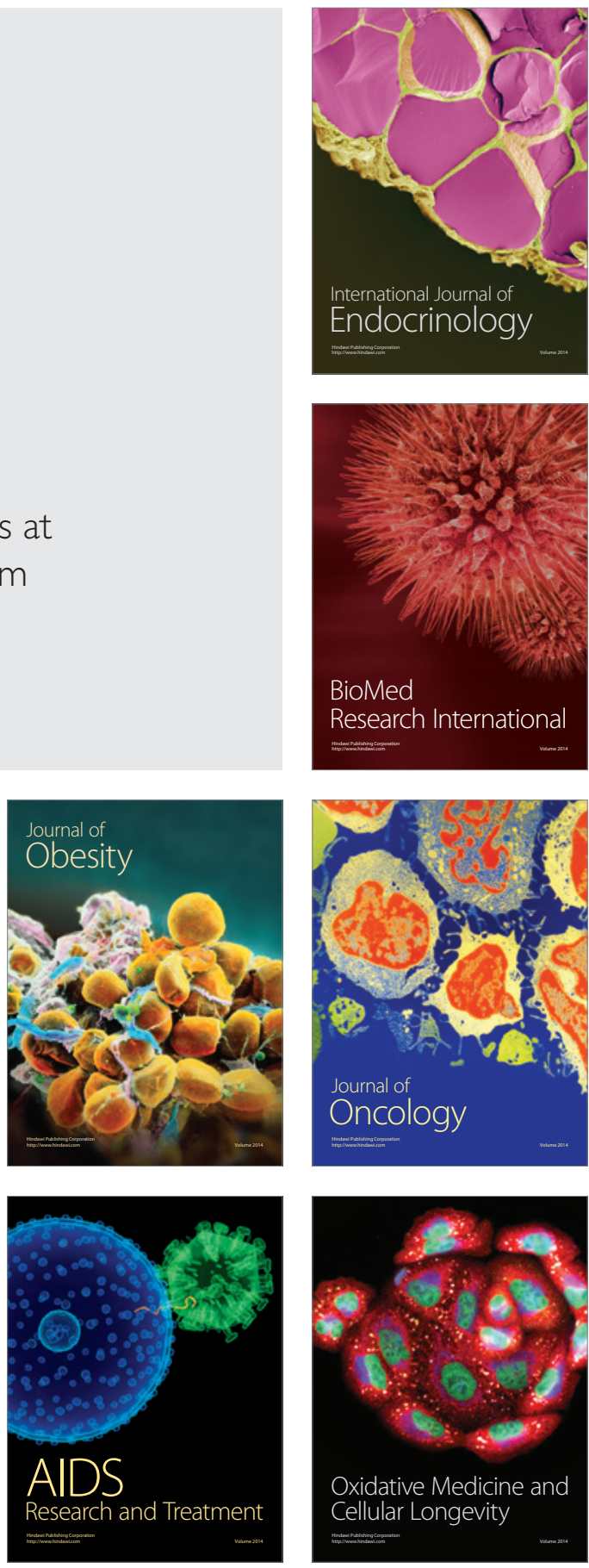